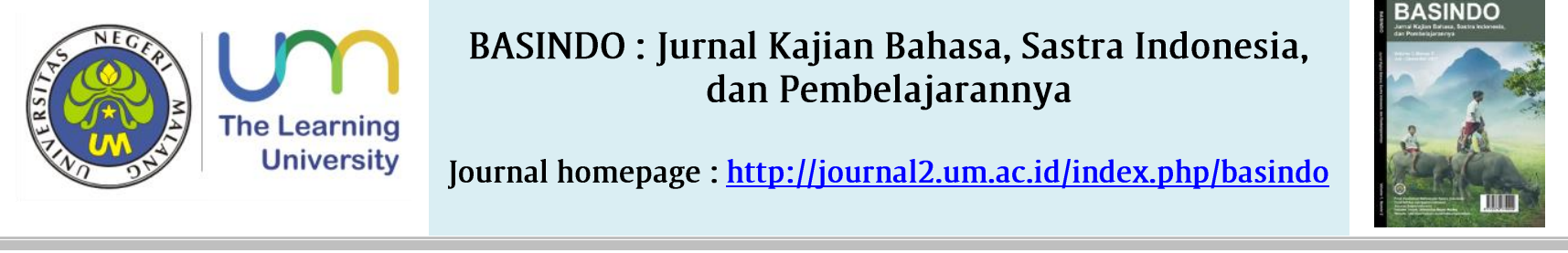

\title{
HUBUNGAN REFERENSI-INFERENSI DALAM WANGSALAN SINDHENAN
}

\author{
Danang Wijoyanto* \\ Universitas Negeri Surabaya
}

\section{A R T I K E L}

Kata Kunci:

hubungan referensi-inferensi wangsalan sindhenan

\begin{abstract}
A B S T R A K
Hubungan referensi-inferensi dalam wangsalan sindhenan adalah pertalian makna atau jawaban teka-teki dengan maksudnya. Jawaban teka-teki atau cangkriman disebut juga batangan, sedangkan maksud wangsalan disebut isi. Penutur dikatakan bisa menafsirkan wangsalan jika mampu menemukan hubungan tersebut. Kenyataannya, banyak masyarakat Jawa yang kesulitan menafsirkan wangsalan sindhenan. Konsep tentang wangsalan tidak hanya dihubungkan dalam pertalian bentuk saja namun juga pertalian makna. Penelitian ini bertujuan mendeskripsikan (1) hubungan bentuk referensi-inferensi dalam wangsalan sindhenan, (2) hubungan isi referensi-inferensi dalam wangsalan sindhenan, dan (3) fungsi pragmastilistika referensi-inferensi dalam wangsalan sindhenan. Pendekatan yang digunakan dalam penelitian ini adalah kualitatif. Pengumpulan data menggunakan metode observasi. Data dianalisis menggunakan metode intertekstualitas dan pragmatik fungsional. Data berwujud kata, frasa dan kalimat wangsalan sindhenan. Data didapatkan dari teks sindhenan dalam rekaman pagelaran wayang kulit tiga generasi dan lintas gagrag. Hasil penelitian ini menghasilkan proposisi: (a) hubungan bentuk fonetikal dan leksikal menjadi tengara referensi-inferensi dalam wangsalan sindhenan (b) hubungan isi konseptual dan asosiatif perwujudan paralelisme semantis referensiinferensi dalam wangsalan sindhenan (c) kemanunggalan fungsi estetis dan ilokusi teraktualisasi dari hubungan referensi-inferensi dalam wangsalan sindhenan.
\end{abstract}

\section{A R T I C L E I N F O}

Keywords:

relation of reference-

inference

wangsalan sindhenan

\begin{abstract}
A B S T R A C T
Relation of reference-inference in wangsalan sindhenan is the connection of meaning or answers to the puzzle with its intent. The answer to a puzzle or cangkriman is also called a bar, while the meaning of wangsalan is called content. Speakers are said to interpret the wangsalan if able to find the relationship. In fact, many Javanese people have difficulty interpreting wangsalan sindhenan. The concept of wangsalan is not only linked in form tangles but also to the connection of meaning. This study aims to describe (1) the relation of reference-inference in wangsalan sindhenan, (2) the relationship of reference-inference content in wangsalan sindhenan , and (3) pragmastylistic function of relation of referenceinference in wangsalan sindhenan. The approach used in this research is qualitative. Data collection using observation method. Data were analyzed using the method of intertextuality and functional pragmatics. The data tangible words, phrases and sentences wangsalan sindhenan. The data were obtained from the text of sindhenan in three league puppet show and cross-gagrag tapes. The results of this study result in the proposition: (a) the relationship of phonetic and lexical forms into a reference-inference landmark in wangsalan sindhenan (b) the conceptual and associative content relationship of the semantic embodiments of reference inferences in wangsalan sindhenan (c) the unity of aesthetic and ilocution actualized function of the relationship of reference-inference in wangsalan sindhenan.
\end{abstract}

(c) 2017 BASINDO Journal. All rights reserved

\section{PENDAHULUAN}

Istilah referensi dalam pragmatik sering tumpang tindih dengan semantik. Istilah tersebut sering disamakan dengan arti leksikal dalam semantik. Menurut Brown (1996:204) istilah referensi dapat dikeluarkan dari pembicaraan tentang arti leksikal dan diperuntukkan bagi fungsi yang digunakan penutur untuk menunjukkan wujud-wujud yang

\footnotetext{
${ }^{*}$ Corresponding author.

E-mail addresses: danangwijoyanto@gmail.com (Danang Wijoyanto)
} 
dibicarakannya (ditulisnya) melalui ungkapan bahasa. Dalam semantik, ungkapan bahasa mengacu wujud-wujud luar bahasa secara universal (Nisa dan Suyitno, 2017), sedangkan dalam pragmatik ungkapan bahasa mengacu wujudwujud luar bahasa sesuai dengan maksud penuturnya. Hal itu berarti, dalam semantik referensi bersifat objektif, edangkan dalam pragmatik referensi bersifat subjektif.

Menurut Brown (1996:35) istilah referensi-inferensi harus diperlakukan sebagai konsep pragmatis. Meskipun dijelaskan terpisah, namun keduanya manunggal dan membentuk suatu hubungan. Istilah tersebut digunakan untuk menunjukkan hubungan-hubungan peserta tutur dan unsur-unsur lain dalam tuturan. Keduanya berkaitan erat dengan koteks dan konteks. Referensi yang berhasil harus memperhatikan peran inferensi. Konsep pragmatis tersebut digunakan untuk strategi interpretasi terhadap wangsalan. Hal itu berarti, wangsalan sebagai gaya bahasa yang bersifat simbolik dan sarat teka-teki dapat dipecahkan dengan analisis pragmastilistika.

Referensi dalam pragmatik merupakan cara mengacu maksud melalui bentuk bahasa yang dipakai oleh penutur untuk menyampaikan pesan kepada petutur (Kushartanti, 2007:110). Artinya penutur menggunakan ungkapan bahasa untuk menyampaikan maksudnya. Tugas petutur yaitu mengidentifikasi referen yang dimaksudkan penutur berdasarkan bentuk bahasa yang digunakan. Tujuannya yaitu untuk memahami pesan bahasa yang berlangsung. Dengan hanya berbekal ungkapan bahasa yang literal saja tentu referensi akan sulit ditemukan.

Referensi dalam wangsalan adalah cara mengacu karep atau maksud melalui cangkriman atau teka-teki yang dibuat oleh penutur. Karep sebagai inferensi dapat ditemukan dalam isi wangsalan. Isi wangsalan berupa fungsi komunikatif yang terselubung dibalik cangkriman. Dalam wangsalan sarung jagung, abot rasaku 'sarung jagung, berat rasaku', bercangkriman sarung jagung. Secara semantis, referensi dari cangkriman tersebut adalah klobot. Batangan tersebut bukan maksud penutur yang sebenarnya. Jawaban atau batangan tersebut sebagai tengara sekaligus daya evokatif isi wangsalan. Wangsalan tersebut berisi berat dan besarnya cinta seseorang. Dalam isi tersebut, kata abot berhubungan fonetikal, yakni adanya pertalian suku kata/bot/. Kemampuan petutur menemukan hubungan referensi-inferensi dalam wangsalan merupakan tanda keberhasilan penafsiran werdi atau arti keseluruhan.

Referensi yang berhasil harus memperhatikan peran inferensi. Keduanya manunggal dan saling berhubungan. Menurut Djajasudarma (2010:41) inferensi dilakukan petutur ketika penutur tidak memunculkan informasi atau maksudnya secara literal dalam wacana yang diungkapkan. Artinya petutur melakukan inferensi ketika menghadapi tuturan terselubung. Pemahaman informasi tak literal digunakan untuk mencapai referensi yang berhasil. Meskipun tak tertulis, informasi tersebut harus dipahami karena ikut menentukan tuturan. Dengan inferensi, petutur akan sampai pada referensi yang sukses.

Inferensi dalam wangsalan adalah penemuan batangan untuk mempertegas keberhasilan referensi. Batangan diperoleh dengan menganalisis cangkriman secara semantis. Batangan sebagai inferensi adalah informasi yang tak literal dan harus dipahami oleh petutur untuk memahami referensi wangsalan. Batangan tersebut tidak diverbalkan namun cukup dikatakan dalam hati. Batangan yang muncul lalu disesuaikan dengan kata-kata yang terdapat dalam isi wangsalan. Penggunaan wangalan sebagai cara yang terselubung menuntut petutur untuk melakukan inferensi.

Referensi-inferensi memiliki hubungan. Yule (1996) menjelaskan agar terjadi referensi yang sukses kita harus mengenali peran inferensi. Artinya referensi-inferensi memiliki suatu hubungan yang mempengaruhi keberhasilan penafsiran seseorang. Peran inferensi adalah mendukung kesuksesan referensi. Inferensi menyimpan suatu informasi yang tak literal dan mendukung keberhasilan suatu referensi. Meskipun demikian belum ada penelitian yang menjelaskan hubungan referensi-inferensi pada objek tertentu. Penelitian yang ada hanya sebatas topik referensi saja dengan mengabaikan peran inferensi. Dengan demikian hubungan referensi-inferensi perlu diteliti untuk menunjukkan keduanya ada suatu hubungan yang tak terpisahkan.

Dalam hal struktur konvensionalnya, wangsalan adalah gaya bahasa dalam bahasa Jawa yang unik dan rumit. Di dalamnya terdapat hubungan referensi-inferensi yang terletak pada pertalian karep penutur dengan batangan. Wijoyanto (2014:14) menjelaskan bahwa struktur wangsalan mirip dengan parikan atau pantun. Artinya wangsalan terdiri atas sampiran dan isi. Bedanya dengan pantun, sampiran dalam wangsalan berupa cangkriman atau teka-teki yang harus ditemukan batangannya. Jika pantun dipertalikan oleh bunyi disetiap akhir barisnya, di dalam wangsalan pertalian bunyi terletak pada batangan dengan karep atau maksud. Karep tersebut berbentuk kata yang terdapat pada isi wangsalan yang berupa pesan penutur. Ketepatan karep dapat diuji dengan hubungan tersebut. Berkat olah pikir orang Jawa, pertalian tersebut tidak hanya berbentuk fonetikal saja namun juga leksikal. Akibatnya dengan adanya pertalian leksikal berpengaruh juga pada tataran isi atau maknanya.

Secara faktual, masyarakat Jawa khususnya anak-anak dan remaja kesulitan untuk menafsirkan sebuah wangsalan. Hal itu karena hubungan referensi-inferensi dalam wangsalan tidak diperhatikan. Sebab yang lain adalah konsep mengenai hubungan referensi-inferensi dalam wangsalan tidak dijelaskan secara rinci. Sebagian besar wangsalan hanya digambarkan sebagai gaya bahasa yang mirip cangkriman dan batangannya diungkapkan secara tersamar. Fokus definisi tersebut hanya tertuju pada penemuan batangan. Padahal batangan tersebut hanya sebagai petunjuk untuk menemukan maksud yang selanjutnya dapat memahami isi komunikatif wangsalan.

Kesulitan lain yang dihadapi adalah perihal penguasaan skemata atau pengetahuan latar belakang budaya Jawa yang kurang. Wangsalan adalah rekaman budaya masa lalu yang penafsirannya juga harus disesuaikan dengan skemata budaya Jawa. Skemata tersebut diantaranya mengenai dunia kesenian, dunia pertanian dan pengetahuan sosiokultural yang lain. Dunia kesenian tersebut menyangkut istilah-istilah dalam dunia pewayangan baik dari alat musik, tokoh dan kasatriannya. Sedangkan dalam dunia pertanian pengetahuan tersebut menyangkut nama-nama tumbuhan, buahbuahan, bagian-bagian tanaman, biji-bijian. Pengetahuan tersebut harus dimiliki oleh masyarakat atau anak jaman sekarang jika ingin menafsirkan wangalan dengan tepat. Tidak heran jika yang mampu menafsirkan wangsalan dari golongan orang tua. 
Karena wangsalan adalah ungkapan yang mirip dengan teka-teki maka sering ditemukan berbagai jawaban yang ambigu dan kabur. Kadarisman (2010:131) menyatakan bahwa secara kultural, maksim "sembunyi itu indah" adalah pegangan utama dalam puitika Jawa klasik. Keambiguan wangsalan memang sengaja dibuat untuk tujuan puitika tersebut. Teka-teki dalam wangsalan banyak yang bermakna umum dan membawa dua makna atau lebih yang harus dipecahkan oleh petutur. Selain itu teka-teki dalam wangsalan juga terdiri dari kata-kata yang terbatas yang mengakibatkan kesamaran atau kekaburan. Terbatas dalam hal ini adalah bentuknya terdiri dari frasa atau klausa yang hanya terdiri dari dua sampai lima kata. Akibatnya petutur akan dibuat berpikir dengan berbagai jawaban yang serba mungkin dan tidak mempunyai batasan yang jelas.

Wangsalan saat ini lebih banyak ditemukan pada teks yang muncul dalam sindhenan. Sindhenan merupakan seni suara Jawa yang dilakukan oleh seseorang berjenis kelamin perempuan. Unsur tekstual sindhenan merupakan lirik atau cakepan yang terdiri dari wangsalan, parikan, abon-abon, sekar tengahan, sekar gedhe maupun sekar bebas. Unsur lagu sindhenan meliputi laras, cengkok dan pathet. Sindhenan merupakan bagian kesatuan dengan karawitan dalam rangka meningkatkan rasa estetik. Wangsalan dalam sindhenan dapat ditemukan pada lirik tembang maupun murni berdiri sendiri sebagai pengisi sebuah iringan gendhing. Wangsalan sebagai gaya bahasa merupakan unsur tekstual yang berfungsi meningkatkan nilai estetik sindhenan. Sindhenan berperan sebagai wahana budaya untuk memperkenalkan dan menjaga wangsalan agar tetap lestari. Maka dari itu keduanya tidak dapat dipisahkan dan membentuk suatu hubungan resiprokal. Artinya keduanya saling mengisi, melengkapi dan membutuhkan.

\section{Identifikasi Hubungan Referensi-Inferensi dalam Wangsalan Sindhenan}

Hubungan referensi-inferensi dalam wangsalan sindhenan berfungsi sebagai penghubung ketaksinambungan antara cangkriman dengan isi wangsalan. Layaknya pantun, cangkriman sebagai sampiran bukanlah pesan yang hendak disampaikan. Pesan yang hendak disampaikan terletak pada isi. Ketidaksinambungan antara sampiran dan isi pada hakikatnya dihubungkan oleh pertalian bunyi. Hubungan referensi-inferensi dalam wangsalan sindhenan terletak pada batangan dengan karep. Hubungan tersebut bersifat terselubung. Artinya sarana penghubung tersebut tersembunyi melalui batangan yang merupakan hasil pemaknaan cangkriman. Batangan tersebut muncul dalam isi wangsalan berbentuk pengulangan bunyi atau leksikal secara parsial. Bahkan hubungan tersebut juga terjadi pada tataran isi atau makna.

Hubungan referensi-inferensi dalam wangsalan sindhenan bersifat asosiatif. Artinya, hubungan tersebut tidak diatur dalam ruang. Hubungan asosiatif yang terdapat pada batangan dengan karep tergantung pada kesemenaan penuturnya. Kesemenaan tersebut didasari oleh hakikat hubungan bentuk. Hubungan bentuk tersebut berupa asosiasi kata dasar maupun suku kata. Akibatnya, penuturpun juga berleluasa meningkatkan hubungan bentuk ke hubungan isi atau makna.

Hakikat hubungan referensi-inferensi dalam wangsalan adalah persamaan bunyi. Persamaan bunyi tersebut digunakan sebagai petunjuk menemukan referensi-inferensi dalam wangsalan. Berkat olah pikir masyarakat Jawa yang tinggi, persamaan bunyi tersebut berkembang pada tataran leksikal dan bahkan isi. Asosiasi tersebut merupakan variasi berdasarkan tanda bahasa. Tanda bahasa tersebut berupa penanda, petanda atau persatuan penanda dan petanda. Hubungan referensi-inferensi dalam wangsalan sindhenan didasari oleh prinsip hubungan bentuk. Karena diatur pada prinsip inilah, hubungan isi wangsalan haruslah digandai dengan hubungan bentuk. Jika hubungan isi tidak disertai hubungan bentuk maka tidak tercipta genre wangsalan.

Menurut Kadarisman (2010:131) batangan wangsalan berfungsi sebagai kata kunci untuk menemukan karep yang muncul secara parsial pada larik isi. Karep wangsalan akan berhasil ditemukan bila mempunyai hubungan parsial dengan batangan. Hubungan parsial berarti antara batangan dan karep hanya bertalian bunyi secara tersamar. Artinya pertalian tersebut hanya perulangan bunyi satu suku kata atau lebih namun tidak sama persis.

Pigeaud (1938:612) mengatakan bahwa wangsalan adalah semacam seni berteka-teki atau sindiran dengan jalan persamaan bunyi. Teka-teki sebagai sampiran harus ditemukan jawabannya. Jawaban tersebut digunakan untuk menyimpulkan dan memahami isi. Sindiran dalam hal ini adalah cara tidak langsung yang digunakan penutur. Isinya dapat berupa nasehat, larangan, saran dan lainnya. Dalam hal ini, persamaan bunyi bunyi untuk menghubungkan cangkriman dengan sindiran. Persamaannya terletak pada batangan dengan maksud dalam isi wangsalan. Artinya hubungan referensi-inferensi dalam wangsalan hanya sekedar pertalian bunyi atau fonetikal.

Wijoyanto (2014:14) mendefinisikan wangsalan sebagai ungkapan yang mirip cangkriman yang batangannya memiliki pertalian bentuk dengan salah satu kata pada isi. Definisi di atas membedakan wangsalan dengan cangkriman. Hal itu ditunjukkan dengan adanya unsur tambahan yaitu mengenai prinsip wangsalan. Prinsip tersebut berupa pertalian bentuk antara batangan dengan karep yang terdapat pada isi. Bentuk tersebut berupa bunyi maupun kata.

Pertalian bunyi maupun kata pada wangsalan disebut juga sebagai piranti emotif (emotive device). Menurut Ullman (2011:166) piranti emotif bertujuan untuk memperkuat dan membangkitkan signifikansi emotif suatu kata. Pertalian bunyi wangsalan berguna untuk menambahkan suatu keindahan yang ikonik. Selain itu, pertalian tersebut juga berguna sebagai rangsangan sekaligus petunjuk untuk menemukan maksud wangsalan.Dengan memperhatikan piranti emotif tersebut penafsir dapat menginferensi wangsalan dengan tepat.

Definisi hubungan referensi-inferensi dalam wangsalan sama-sama dijelaskan mengenai hubungan bentuk. Berbagai perbedaan muncul tentang jenis hubungan bentuk tersebut. Pola tersebut ada yang hanya berupa fonetikal atau bunyi namun juga ada yang leksikal. Hubungan bunyi atau fonetikal dapat berupa pertalian satu suku kata atau lebih. Hubungan leksikal artinya antara batangan dan karep memiliki persamaan dalam hal kata dasar. Dengan adanya hubungan leksikal maka berakibat adanya hubungan makna atau isi.

Kesimpulannya, hubungan referensi-inferensi dalam wangsalan ditemukan pada batangan sebagai referensi dengan karep sebagai inferensi. Hubungan referensi-inferensi dalam wangsalan memiliki dua tipe yaitu hubungan 
bentuk dan isi. Hubungan bentuk terdiri atas bentuk fonetikal dan bentuk leksikal. Hakikat hubungan bentuk tersebut adalah pertalian bunyi. Pertalian leksikal adalah pengembangan dari bunyi sebagai satuan bahasa terkecil ke bentuk kata yang lebih besar. Hubungan leksikal dapat dikembangkan pula pada hubungan isi atau maknanya.

\section{Klasifikasi Hubungan Referensi-Inferensi dalam Wangsalan Sindhenan}

Hubungan referensi-inferensi dalam wangsalan sindhenan diklasifikasikan berdasarkan keasosiatifannya menjadi dua yaitu hubungan bentuk dan isi. Hubungan bentuk referensi-inferensi dalam wangsalan sindhenan ditandai dengan adanya pertalian fonetikal dan leksikal. Hubungan isi referensi-inferensi dalam wangsalan sindhenan ditandai dengan adanya pertalian makna konseptual dan asosiatif. Klasifikasi tersebut dijelaskan di bawah ini.

\section{a. Hubungan Bentuk Referensi-Inferensi dalam Wangsalan Sindhenan}

Hakikat hubungan bentuk referensi-inferensi adalah pertalian bunyi. Pertalian bunyi tersebut dapat dikembangkan menjadi leksikal dengan olah pikir yang lebih. Hubungan bentuk referensi berdasarkan piranti emotifnya dibagi menjadi dua yaitu fonetikal dan leksikal.

Hubungan bentuk fonetikal referensi-inferensi dalam wangsalan sindhenan ditandai dengan pertalian suku kata. Pertalian suku kata tersebut dijadikan tengara untuk menemukan referensi-inferensi wangsalan sindhenan. Menurut Kadarisman (2010:131) batangan wangsalan berfungsi sebagai kata kunci untuk menemukan karep yang muncul secara parsial pada larik isi. Karep wangsalan akan berhasil ditemukan bila mempunyai hubungan parsial dengan batangan. Hubungan parsial berarti antara batangan dan karep hanya bertalian bunyi secara tersamar. Artinya pertalian tersebut hanya perulangan bunyi satu suku kata atau lebih namun tidak sama persis.

Semakin kontras hubungan referensi-inferensi penafsiran petutur terhadap wangsalan semakin mudah. Menurut Wahab (1991:26) petutur atau pendengar berusaha memahami makna suatu tuturan dengan kerja indra pendengar sekecil mungkin. Artinya, ia menghendaki adanya segmen-segmen bunyi bahasa yang cukup kontras dan jelas baginya. Akibatnya semakin samar atau sedikit kekontrasan hubungan referensi-inferensi maka penafsirannya semakin lama dan sulit.

Berdasarkan proses produksi wangsalan, penutur sebagai decoder selalu ingin menampilkan hubungan fonetikal dengan tenaga dan gerak artikulasi sesedikit mungkin. Menurut Wahab (1991:26) perilaku manusia dalam berbahasa yang merupakan jilmaan dari hukum alam ialah kebiasaan manusia mencari jalan sependek mungkin dalam upayanya mencapai tujuan. Akibatnya, penutur cenderung menghasilkan ujaran dengan berbagai bentuk artikulasi bunyi yang mudah dicapai. Penutur sebagai decoder cenderung membuat hubungan fonetikal dengan sedikit pertalian suku kata. Suku kata tersebut cenderung diletakkan dan diambil diposisi awal atau akhir sebuah kata. Hal itu wujud aktualisasi pencarian jalan sependek mungkin memproduksi wangsalan sindhenan. Jalan seperti itu tidak membuat penutur berpikir keras namun membuat petutur berpikir lebih keras.

Suku kata dalam sebuah kata dapat menduduki posisi di awal, tengah dan akhir. Kata yang terdiri dari satu suku kata tidak berposisi. Hal itu berarti kata yang terdiri dari dua suku kata hanya terdiri dari dua posisi yaitu posisi awal dan akhir. Posisi awal, tengah dan akhir dimiliki kata yang terdiri atas tiga suku kata atau lebih. Bentuk referensiinferensi dalam wangsalan sindhenan adalah kata. Kata tersebut tidak ada yang terdiri dari satu suku kata. Kata sebagai bentuk referensi-inferensi dalam wangsalan sindhenan terdiri dua suku kata dan lebih.

\section{b. Hubungan Isi Referensi-Inferensi dalam Wangsalan Sindhenan}

Hubungan isi referensi-inferensi dalam wangsalan sindhenan terbagi dalam dua jenis makna yaitu konseptual dan asosiatif. Hubungan asosiatif dapat dibagi lagi menjadi asosiatif konotatif, asosiatif stilistik, dan asosiatif kolokatif. Menurut Leech (2003:19) makna konseptual kadang disebut juga makna denotatif atau makna kognitif dalam pengertian luas dianggap faktor sentral dalam komunikasi bahasa. Hal ini dapat ditunjukkan sebagai sesuatu yang terpadu bagi fungsi esensial terhadap suatu bahasa, tidak seperti makna yang lain. Alasan utama untuk menempatkan sebagai prioritas pada makna konseptual adalah bahwa makna konseptual mempunyai susunan yang amat kompleks dan rumit. Khususnya pada dua prinsip struktural yaitu kontrasitif dan struktur konsitituen.

Hubungan asosiatif konotatif merupakan makna konseptual yang mendapatkan tambahan terhadap apa yang diacu. Menurut Leech (2003:21) makna konotatif merupakan nilai komunikatif dari satu ungkapan menurut apa yang telah diacu, melebihi diatas isinya yang murni konseptual. Sejauh itu pengertian acuan bertumpah tindih dengan makna konseptual. Contoh kata wanita apabila dibuat definisinya dalam konseptual maka sifat itu adalah manusia, dewasa, dan perempuan haruslah memberikan kriteria secara benar. Sifat sebaliknya kedalam dunia nyata menjadi atribut dari acuannya. Tetapi juga sejumlah sifat tambahan yang tidak masuk dalam kriteria itu, yang kita ketahui juga dapat jadi acuan kata woman tersebut. Acuan tersebut tidak hanya meliputi sifat psikis (berkaki dua, memiliki rahim) tetapi bersifat psikis dan sosial (suka berteman, memiliki naluri keibuan) dan dapat diperluas kearah-arah yang bersifat tipikal bukannya selalu ada dalam kewanitaan (pandai bicara, pandai masak, memakai rok, gaun). Masih dapat diteruskan lagi makna konotatifnya meliputi sifat putatif dari acuannya, disebabkan pandangan yang diterima oleh individu atau sekelompok atau seluruh anggota masyarakat seperti (lemah, gampang menangis, penakut, emosional, tidak rasional, tidak konstan).

Membicarakan konotasi akan semakin jelas bila berbicara tentang dunia nyata yang diasosiakan dengan ungkapan ketika sesorang mendengarnya atau menggunakannya. Oleh karena itu, batas antara makna konseptual dengan makna konotatif juga merupakan batas yang kabur tetapi penting untuk diketahui.

Hubungan asosiatif stilistik merupakan makna yang berhubungan dengan gaya bahasa suatu lingkungan tertentu. Berbicara tentang makna sitilistik berarti membicarakan dua aspek komunikasi yang berhubungan dengan situasi terjadinya ucapan. Menurut Leech (2003:25) makna stilistik adalah makna sebuah kata yang menunjukkan lingkungan sosial penggunaannya. Kita mengenali beberapa kata atau ucapan sebagai suatu dialek yaitu menunjukkan tentang asal-usul penutur menurut lingkungan geografis atau lingkungan sosialnya. Ciri lainya adalah bahasa menunjukkan 
sesuatu tentang hubungan sosial antara penutur dengan pendengarnya, misalnya bahasa sehari-hari, kekeluargaan, bahasa slang.

Hubungan asosiatif kolokatif merupakan hubungan makna kata batangan sebagai akibat makna kata karep. Menurut Leech (2003:29) makna kolokatif terdiri atas asosiasi-asosiasi yang diperoleh suatu kata, yang disebabkan oleh makna kata-kata yang cenderung muncul di dalam lingkungannya. Kata-kata prety dan handsome memiliki arti kata dasar yang sama dalam arti sedap dipandang namun kedua kata itu dapat dibedakan menurut beberapa kata benda lain yang menyertainya atau menjadi kata sandingnya.

Makna kolokatif, stilistik dan konotatif bagian dari makna asosiatif. Ketiganya lebih bersifat terbuka. Makna asosiatif adalah makna yang kurang stabil dan bervariasi menurut pengalaman individu.makna asosiatif mengandung banyak faktor yang amat rumit, sehingga kita baru bisa mempelajarinya secara sistematis jika memakai teknik statistik yang memadai. Oleh sebab itu, Osgood, Suci dan Tannebaum mengemukakan metode analisis parsial terhadap makna asosiatif dalam buku mereka yang berjudul The Meassurement of Meaning pada tahun 1957. Osgood dan rekanrekannya menggunakan suatu teknik (yang melibatkan sebuah alat pengukur statistik yang disebut Semantik Differential) untuk menemukan makna menurut suatu wawasan semantik multi-dimensional, dengan menggunakan penilaian penutur sebagai data dan itu dicatat dalam bentuk skala tujuh butir.

\section{Fungsi Pragmastilistika Hubungan Referensi-Inferensi dalam Wangsalan Sindhenan}

Wangsalan diasumsikan sebagai bentuk simbolis yang digunakan penutur untuk melaksanakan fungsi puitis. Menurut Jakobson (1960:71) fungsi puitis berfokus pada bahasa itu sendiri dan menonjolkan bentuk bahasa demi dampak estetis. Bahasa puitis lazimnya ditandai oleh rima dan atau aliterasi pada lapis fonologis, paralelisme pada lapis sintaksis, dan paralelisme-kontras pada tahap semantis. Fungsi puitis ditunjukkan dengan keseimbangan bentuk dan isi yang diproyeksikan dari poros paradigmatik pada poros sintagmatik. Poros paradigmatik adalah bahasa yang secara universal merepresentasikan realitas. Sedangkan poros sintagmatik ditandai dengan adanya manipulasi bentuk maupun makna demi tercapai kaidah keindahan. Artinya letak bentuk tidak bisa ditukar dan diganti karena akan mempengaruhi keindahannya.

Hubungan referensi-inferensi dalam wangsalan menunjukkan adanya suatu paralelisme. Artinya terdapat suatu pengulangan bentuk maupun isi di dalamnya. Pengulangan bentuk dan isi dalam wangsalan secara stilistis menegaskan isi wangsalan. Isi wangsalan adalah pesan komunikatif yang disampaikan penutur. Dengan adanya hubungan tersebut pesan tersebut akan mudah diingat.

Menurut Black (2011:268) simbol mempunyai berbagai sifat di antaranya yaitu bersifat alusif (merujuk secara tidak langsung) dan elusif (tidak memiliki batasan yang jelas). Selain itu simbol bersifat sugestif (memberikan gambaran tak langsung) dan tidak menyatakan secara eksplisit. Cara kerja dari simbolisme yang seperti ini disebut sebagai efek puitis.

Wangsalan dalam hal ini juga termasuk simbol yang juga mempunyai sifat-sifat alusif, elusif, sugestif dan implisit. Untuk mengetahui referensi wangsalan kita harus merujuk pada koteks dan konteks. Cangkriman dalam wangsalan juga tidak memiliki batasan yang jelas. Dengan cangkriman yang katanya terbatas kita dituntut untuk mampu menemukan batangan. Batangan tersebut lalu digunakan sebagai petunjuk menemukan referensi. Wangsalan juga menyugesti petutur untuk memikirkan sesuatu hal melalui cangkriman dan batangan. Dengan adanya wangsalan sebagai alat menyampaikan maksud maka sudah jelas cara yang digunakan tidak eksplisit.

Selain berfungsi puitis, wangsalan mengemban suatu fungsi pragmatis. Di dalam wangsalan selalu ada pesan komunikatif yang dapat ditemukan pada isi wangsalan sebagai sebuah tindak tutur. Eco (dalam Black, 2011:267) mengajukan beberapa ide tentang penciptaan dan penerimaan terhadap simbol yang meletakkan simbol di dalam konteks interpersonal, sama seperti pendekatan pragmatis dalam penafsiran. Konteks interpersonal dalam hal ini berarti penggunaan bahasa untuk menunjukkan sikap penutur dan menjaga hubungan penutur dengan petutur. Wangsalan sebagai tindak tutur digunakan untuk mengungkapkan pikiran maupun perasaan penutur yang bersifat ilokusif. Sifat tersebut dapat dilihat dari isi wangsalan. Isi tersebut dapat berupa nasihat, ungkapan perasaan, larangan dan lain-lain. Penggunaan wangsalan juga digunakan untuk menjaga keharmonisan antara penutur dengan petutur.

Klasifikasi umum mencantumkan lima jenis fungsi umum yang ditunjukkan oleh tindak tutur: deklaratif, representatif, ekspresif, direktif, dan komisif (Yule, 2006: 92-94). Tindak tutur deklaratif adalah tindak tutur yang mengubah dunia melalui tuturan. Tindak tutur representatif adalah tindak tutur yang menyatakan apa yang diyakini penutur kasus atau bukan. Tindak tutur ekspresif adalah tindak tutur yang menyatakan sesuatu yang dirasakan oleh penutur. Tindak tutur direktif adalah tindak tutur yang dipakai oleh penutur untuk menyuruh orang lain melakukan sesuatu. Tindak tutur komisif adalah tindak tutur yang dipahami oleh penutur untuk mengikatkan dirinya terhadap tindakan-tindakan di masa yang akan datang.

Penelitian ini bertujuan mendeskripsikan hubungan referensi-inferensi dalam wangsalan sindhenan. Deskripsi tersebut difokuskan pada hubungan bentuk, hubungan isi dan fungsi pragmastilistikanya.

\section{METODE}

Pendekatan yang digunakan dalam penelitian ini adalah kualitatif. Pengumpulan data menggunakan metode observasi. Data dianalisis menggunakan metode intertekstualitas dan pragmatik fungsional. Data berwujud kata, frasa dan kalimat wangsalan sindhenan. Data didapatkan dari teks sindhenan dalam rekaman pagelaran wayang kulit tiga generasi dan lintas gagrag.

HASIL

Hubungan bentuk referensi-inferensi dalam wangsalan sindhenan berdasarkan perabot emotifnya diklasifikasikan menjadi dua yaitu fonetikal dan leksikal. Hubungan bentuk fonetikal diklasifikasikan berdasarkan persilangan pemosisisian bunyi suku kata dalam sebuah kata menjadi delapan yaitu (a) pemosisian bunyi di awal-awal, (b) pemosisian bunyi di awal-tengah, (c) pemosisian bunyi di tengah-awal, (d) pemosisian bunyi di tengah-tengah, (e) 
pemosisian bunyi di tengah-akhir, (f) pemosisian bunyi di akhir-awal, (g) pemosisian bunyi di akhir-tengah, dan (i) pemosisian bunyi di akhir-akhir. Hubungan bentuk leksikal berdasarkan ada tidaknya imbuhan dibagi menjadi empat yaitu (a) berimbuhan zero, (b) berimbuhan prefiks, (c) berimbuhan infiks, (d) berimbuhan sufiks. Artinya, imbuhan konfiks tidak ditemukan pada hubungan leksikal.

Berdasarkan tipe maknanya, hubungan isi referensi-inferensi dalam wangsalan sindhenan dibagi menjadi dua yaitu konseptual dan asosiatif. Hubungan asosiatif dibagi dibagi berdasarkan keterbukaan maknanya menjadi (a) asosiatif konotatif, (b) asosiatif stilistik, (c) asosiatif kolokatif.

Fungsi pragmastilistika hubungan referensi-inferensi dalam wangsalan sindhenan dibagi berdasarkan dua fungsi dominannya. Fungsi tersebut adalah fungsi pragmatis dan fungsi stilistis. Kedua fungsi tersebut disilangkan sehingga menghasilkan enam jenis fungsi pragmastilistika yaitu (a) intensif asertif, (b) intensif direktif, (c) intensif ekspresif, (d) elusif asertif, (e) elusif direktif, (f) elusif ekspresif.

\section{PEMBAHASAN}

1. Hubungan Bentuk Fonetikal dan Leksikal Menjadi Tengara Referensi-Inferensi dalam Wangsalan Sindhenan

Hubungan bentuk fonetikal dan leksikal referensi-inferensi dalam wangsalan sindhenan yang bersifat terselubung merupakan wujud internalisasi aspek kultural Jawa. Menurut Kadarisman (2002:5) budaya Jawa memiliki ciri khas pada kesirkuleran atau ketaklangsungannya. Modus berpikir melingkar itu juga muncul, antara lain, sebagai the principle of indirectness atau "prinsip tak langsung." Salah satu ungkapan terkenal dalam budaya Jawa adalah tanggap ing sasmita, atau "tajam menangkap isyarat," betapa pun samar atau lembutnya isyarat itu. Dalam penafsiran wangsalan sindhenan, batangan dan karep memiliki hubungan pertalian bunyi yang keduanya dapat digunakan sebagai isyarat. Isyarat tersebut digunakan untuk menemukan werdi atau arti keseluruhan dari wangsalan sindhenan.

Hubungan referensi-inferensi dalam wangsalan sindhenan bersifat asosiatif. Artinya, hubungan tersebut tidak diatur dalam ruang. Pengelompokan itu didasarkan pada keanekaan hubungan yang dapat diciptakan. Hubungan asosiatif yang terdapat pada batangan dengan karep tergantung pada kesemenaan penuturnya. Kesemenaan tersebut didasari oleh hakikat hubungan bentuk. Hubungan bentuk tersebut berupa asosiasi kata dasar maupun suku kata. Akibatnya, penuturpun juga berleluasa meningkatkan hubungan bentuk ke hubungan isi atau makna. Secara sadar atau tidak pengasosiasian karep dengan batangan sangat dipengaruhi oleh konteks budaya yang melingkupinya.

Hubungan fonoleksikal menjadi tengara atau sasmita mengungkap werdireferensi-inferensi dalam wangsalan sindhenan. Menurut Djajasudarma (1993:53) arti atau werdi yaitu hubungan antara tanda yang berupa lambang bunyi dalam ucapan dengan kejadian yang dimaksudkan.Werdi atau arti keseluruhan wangsalan sindhenan didapat dengan menginterpretasi teges (makna) dan karep (maksud). Untuk menemukan teges atau makna petutur terlebih dahulu menganalisis wujud cangkriman secara leksikal dan gramatikal. Analisis teges atau makna melalui wujuddilakukan untuk menjawab batangan atau jawaban teka-teki yang dimaksud oleh penutur. Karena jawaban teka-teki tersebut bersifat subjektif, maka kebenarannya teruji pada isi wangsalan sindhenan. Isi wangsalan terkandung pesan ilokutif asertif, direktif dan ekspresif. Dalam isi wangsalan sindhenan terdapat kata yang bertalian bentuk serta bentuk dan isi. Barulah referensi-inferensi dalam wangsalan sindhenan ditemukan. Yang artinya, petutur mampu menemukan werdi wangsalan sindhenan.

2. Hubungan Isi Konseptual dan Asosiatif Perwujudan Paralelisme Semantis Referensi-Inferensi dalam Wangsalan Sindhenan

Hakikat hubungan referensi-inferensi dalam wangsalan adalah persamaan bunyi. Persamaan bunyi tersebut digunakan sebagai petunjuk menemukan referensi-inferensi dalam wangsalan. Berkat olah pikir masyarakat Jawa yang tinggi, persamaan bunyi tersebut berkembang pada tataran leksikal dan bahkan isi. Tanda bahasa tersebut berupa penanda, petanda atau persatuan penanda dan petanda. Hubungan referensi-inferensi dalam wangsalan sindhenan didasari oleh prinsip hubungan bentuk. Karena diatur pada prinsip inilah, hubungan isi wangsalan haruslah digandai dengan hubungan bentuk. Jika hubungan isi tidak disertai hubungan bentuk maka tidak tercipta genre wangsalan.

Hubungan isi referensi-inferensi dalam wangsalan teraktualisasi pada variasi makna asosiatif dan konseptual. Variasi hubungan asosiatif referensi-inferensi dalam wangsalan sindhenan meliputi hubungan asosiatif stilistik, asosiatif konotatif, dan asoiasi kolokatif. Menurut Leech (1993) makna konseptual merupakan bagian besar dari common system yang dimiliki anggota masyarakat lisan sedangkan makna asosiatif makna yang kurang stabil. Makna konseptual bersifat universal sedangkan makna asosiatif bersifat relatif. Universalitas makna konseptual tersebut ditandai dengan banyaknya orang yang mengenal makna tersebut karena memiliki persamaan. Relativitas makna asosiatif ditandai dengan banyaknya variasi yang muncul karena didasari oleh pengalaman individu. Hubungan konseptual akan mudah diinterpretasi oleh banyak orang sedangkan hubungan asosiatif lebih sulit. Hubungan konseptual bersifat jelas sedangkan hubungan asosiatif bersifat elusif atau kabur.

3. Kemanunggalan Fungsi Estetis dan Ilokusi Teraktualisasi Hubungan Referensi-Inferensi dalam Wangsalan Sindhenan

Dalam kultural Jawa, baik dari aspek estetik maupun etik, prinsip ketidaklangsungan atau ketersembunyian benarbenar dihayati oleh masyarakat Jawa. Prinsip semakin sembunyi semakin indah juga terinternalisasi pada hubungan referensi-inferensi dalam wangsalan sindhenan. Untuk menemukan keindahan berupa aliterasi, asonansi maupun repetisi leksikal yang tercipta, petutur diwajibkan menjawab cangkriman terlebih dahulu. Artinya, paralelisme fonetis, morfologis maupun semantis yang tercipta bersifat terselubung dan tidak dapat langsung ditemukan. Selain itu katakata arkaik yang digunakan sebagai cangkriman menambah ketersembunyiannya untuk menguak makna batangan sebagai referensi. Dalam kultur Jawa, karya sastra yang terkandung bahasa Kawi dianggap memiliki tingkat kesastraan yang tinggi. Hal itu berkaitan tentang prinsip ketersembunyian.

Kesopanan dalam wangsalan sindhenan diwujudkan melalui keindahan. Keindahan tersebut tercipta melalui nada dan bentuk bahasa. Keindahan nada tercipta melalui suara merdu yang dinyanyikan oleh sinden. Keindahan bentuk 
bahasa tersebut tercipta melalui paralelisme baik dari aspek fonologis, morfologis, sintaktis dan semantis.Paralelisme dari aspek fonologis berbentuk aliterasi, asonansi, serta rima yang terdapat pada wangsalan sindhenan. Paralelisme tersebut

Hubungan referensi-inferensi dalam wangsalan menciptakan sarana puitika berupa paralelisme. Paralelisme terebut terjadi pada tataran bentuk dan isi. Paralelisme pada tataran bentuk meliputi asonansi, aliterasi dan repetisi leksikal.Sarana puitika ini bersifat terselubung. Artinya petutur dapat menemukan keindahannya jika mampu menjawab teka-teki dari wangsalan yang dimaksud penutur. Sarana tersebut selain berfungsi sebagai penegas namun juga sebagai pengabur. Fungsi penegas digunakan agar pesan yang disampaikan selalu diingat. Sarana puitika yang digunakan berupa paralelisme berupa asonansi, aliterasi dan repetisi leksikal. Sarana tersebut teraktualisasikan melalui hubungan bentuk leksikal zero.Sedangkan fungsi pengabur atau elusif digunakan untuk menyamarkan pesan yang berpotensi mengancam muka mitratutur. Pesan tersebut diantaranya menasehati, melarang dan menyuruh. Fungsi pengabur tersebut mengejawantah pada hubungan bentuk fonetikal yang jumlah persamaan suku katanya sedikit.

Aspek etik atau kesopanan dalam wangsalan sindhenan terinternalisasi dengan adanya cangkriman yang mendahului isi. Kedudukan cangkriman dalam wangsalan sindhenan sama dengan sampiran dalam pantun. Artinya ada basa-basi yang mendahului sebelum mengungkapkan pesan penutur. bentuk fonoleksikal dan isi-lah yang fungsinya sebagai penghubung ketidak sinambungan antara cangkriman dan isi wangsalan sindhenan. Dengan adanya sampiran tersebut, pesan yang berpotensi menyinggung perasaan dapat dikurangi. Artinya prinsip kesopanan berupa ketidaklangsunan terrefleksi pada hubungan referensi-inferensi dalam wangsalan sindhenan. Bertutur dengan menggunakan wangsalan sindhenan dengan cara dinyanyikan lebih sopan, lebih enak dirasakan dan mudah diingat daripada bertutur dengan cara wantah'lugas' tanpa tedheng aling-aling 'pengabur berupa basa-basi'. Dengan demikian fungsi stilistis yang terdapat pada hubungan referensi-inferensi dalam wangsalan sindhenan digunakan untuk mendukung fungsi pragmatis.

\section{PENUTUP}

\section{Simpulan}

Hubungan bentuk referensi-inferensi dalam wangsalan sindhenan berdasarkan perabot emotifnya diklasifikasikan menjadi dua yaitu fonetikal dan leksikal. Hubungan bentuk fonetikal diklasifikasikan berdasarkan persilangan pemosisisian bunyi suku kata dalam sebuah kata menjadi delapan yaitu (a) pemosisian bunyi di awal-awal, (b) pemosisian bunyi di awal-tengah, (c) pemosisian bunyi di tengah-awal, (d) pemosisian bunyi di tengah-tengah, (e) pemosisian bunyi di tengah-akhir, (f) pemosisian bunyi di akhir-awal, (g) pemosisian bunyi di akhir-tengah, dan (i) pemosisian bunyi di akhir-akhir. Teori tentang afiksasi disebutkan ada empat jenis afiks yaitu prefiks, infiks, sufiks dan konfiks. Hubungan bentuk leksikal berdasarkan ada tidaknya imbuhan dibagi menjadi empat yaitu (a) berimbuhan zero, (b) berimbuhan prefiks, (c) berimbuhan infiks, (d) berimbuhan sufiks. Artinya, imbuhan konfiks tidak ditemukan pada hubungan leksikal.

Berdasarkan tipe maknanya, hubungan isi referensi-inferensi dalam wangsalan sindhenan dibagi menjadi dua yaitu konseptual dan asosiatif. Hubungan asosiatif dibagi dibagi berdasarkan keterbukaan maknanya menjadi (a) asosiatif konotatif, (b) asosiatif stilistik, (c) asosiatif kolokatif. Artinya, jenis makna yang tidak ditemukan dalam hubungan isi adalah asosiatif afektif, asosiatif reflektif dan tematik.

Fungsi pragmastilistika hubungan referensi-inferensi dalam wangsalan sindhenan dibagi berdasarkan dua fungsi dominannya. Fungsi tersebut adalah fungsi pragmatis dan fungsi stilistis. Berdasarkan teori tindak tutur, klasifikasi umum mencantumkan lima jenis fungsi umum yang ditunjukkan oleh tindak tutur: deklaratif, representatif, ekspresif, direktif, dan komisif. Fungsi pragmatis yang ditemukan meliputi asertif, direktif dan ekspresif. Fungsi stilistis mengacu pada fungsi simbolisme yaitu sugestif, alusif, intensif dan elusif. Fungsi yang ditemukan hanya ada dua yaitu fungsi intensif dan alusif. Kedua fungsi tersebut disilangkan sehingga menghasilkan enam jenis fungsi pragmastilistika yaitu (a) intensif asertif, (b) intensif direktif, (c) intensif ekspresif, (d) elusif asertif, (e) elusif direktif, (f) elusif ekspresif.

Saran

Saran yang dapat dijadikan sebagai bahan masukan untuk peneliti selanjutnya adalah perlunya penelitian mengenai jenis hubungan referensi-inferensi dengan lokus yang lain. Penelitian tersebut tidak hanya dalam wangsalan sindhenan saja namun dapat pula dalam jenis metafora Jawa seperti pepindhan, isbat, paribasan, dan lain sebagainya. Hubungan referensi-inferensi juga akan lebih fokus jika dikhususkan pada jenis hubungan tertentu. Tentu hal itu harus disesuaikan dengan lokus dan modusnya.

Saran yang dapat dijadikan sebagai bahan masukan untuk para guru adalah perlunya perubahan konsep bahwa wangsalan hanya dipertalikan oleh hubungan bunyi saja. Konsep tersebut harus diperbaharui bahwa prinsip wangsalan tidak hanya berupa bentuk fonetikal berupa suku kata namun juga leksikal dan bahkan makna atau isi. Prinsip hubungan bentuk dan isi dalam wangsalan digunakan untuk memproduksi wangsalan maupun menafsirkan wangsalan oleh siswa.

Saran yang dapat dijadikan sebagai bahan masukan untuk seniman adalah perlunya memahami wangsalan sindhenan yang dilagukannya. Kepahaman sindhen terhadap werdi wangsalan sindhenan yang dilagukan akan menambah kualitas sindhen itu sendiri. Untuk menemukan werdi, maka sindhen menggunakan prinsip hubungan bentuk dan isi. Kualitas sindhen selain dinilai dari kualitas vokal namun juga kecerdasan dan penghayatannya. Bukan tidak mungkin, dengan selalu mengasah pikiran menemukan werdi wangsalan sindhenan, seorang sindhen akan mampu menciptakan wangsalan sindhenan baru dengan menyesuaikan konteks pada saat ini.

Saran kepada para seniman yang ingin menciptakan wangsalan sindhenan baiknya tetap berprinsip pada estetika, etika budaya Jawa serta konteks kekinian. Sudah saatnya, wangsalan sindhenan sekarang berisi nasehat tentang keadaan sosial-politik di masa sekarang. Mengkritisi tentang pentingnya hidup rukun antar umat beragama, santun dalam berbicara serta mengamalkan ajaran suci agama tentang kasih dan damai. Melalui wangsalan yang baru dengan 
konteks yang baru maka wangsalan sindhenan akan sangat berguna. Wangsalan sindhenan tersebut berguna sebagai alat pemersatu bangsa seperti wangsalan sindhenan pada era kemerdekaan dahulu. Wangsalan juga akan sebagai perekam kebudayaan masa sekarang yang dapat digunakan di masa yang akan datang.

\section{DAFTAR PUSTAKA}

Black, Elizabeth. 2001. Stilistika Pragmatis. Yogyakarta: PustakaPelajar

Brown G.\&Yule, G. 1996. Analisis Wacana. Jakarta: Gramedia Pustaka Utama

Djajasudarma, T. Fatimah. 1994. Wacana Pemahaman dan Hubungan Antarunsur. Bandung: Eresco

Jakobson, Roman.1960. Linguistics and Poetics. In Pomorska, K. \& Rudy, S. Roman Jakobson, Language in Literature, pp. 62-94. Cambridge, Mass., London,England: The Belknap Press of Harvard University Press.

Kadarisman, A. Effendi. 2002. Etnopuitika: Dari Bunga-rampai Teks dan Pentas Sampai ke Akar Budaya. Makalah disajikan pada Metodologi Penelitian dan Seni Pertunjukan Indonesia, di Sekolah Tinggi Seni Indonesia, Surakarta, Juli 2002

Kadarisman, A Effendi. 2010. Mengurai Bahasa Menyibak Budaya Bunga Rampai Linguistik, Puitika, dan Pengajaran Bahasa. Malang: UIN-Maliki Press

Kushartanti, Untung Yuwono, Multamia RMT Lauder. 2007. Pesona Bahasa: Langkah awal Memahami Linguistik. Jakarta: Gramedia Pustaka Utama

Leech, Geoffrey. 1993. Prinsip-prinsip Pragmatik. Jakarta: Penerbit Universitas Indonesia

Nisa, K dan Suyitno, I. (2017). Kesalahan Penggunaan Bahasa Indonesia dalam Teks Terjemahan Mahasiswa. Basindo: Jurnal Kajian Bahasa, Sastra Indonesia, dan Pembelajarannya, Volume 1 Nomor 1 2017, hal. 1-13, http://dx.doi.org/10.17977/um007v1i12017p001

Pigeaud, Dr. Th. 1938. Javaans-Nederlands Handwordenboek. Batavia: J.B. Wolters-Groningen

Ullman, Stephen. 2011. Pengantar Semantik. Yogyakarta: Pustaka Pelajar

Wahab, Abdul. 1991. Isu Linguistik Pengajaran Bahasa dan Sastra. Surabaya: Airlangga University Press

Wijoyanto, Danang. 2014. "Ngripta lan Negesi Wangsalan".Dalam Majalah: Jayabaya No. 04 Minggu IV September 2014. Surabaya: Temprina Media Grafika

Yule, George. 1996. Pragmatik(Terjemahan Indah Fajar Wahyuni). Yogyakarta: Pustaka Pelajar. 